DIGITAL COMMONS
@ UNIVERSITY OF SOUTH FLORIDA

Volume 9

Issue 1 Special Issue: Eighteenth-Century Camp
ABO: Interactive Journal for

Women in the Arts, 1640-1830

2019

\title{
Representing Camp: Constructing Macaroni Masculinity in Eighteenth-Century Visual Satire
}

\author{
Freya Gowrley \\ University of Edinburgh, f.l.gowrley@gmail.com
}

Follow this and additional works at: https://digitalcommons.usf.edu/abo

Part of the Ancient, Medieval, Renaissance and Baroque Art and Architecture Commons, Feminist, Gender, and Sexuality Studies Commons, and the Illustration Commons

\section{Recommended Citation}

Gowrley, Freya (2019) "Representing Camp: Constructing Macaroni Masculinity in Eighteenth-Century Visual Satire," ABO: Interactive Journal for Women in the Arts, 1640-1830: Vol.9: Iss.1, Article 4. https://doi.org/10.5038/2157-7129.9.1.1171

Available at: https://digitalcommons.usf.edu/abo/vol9/iss1/4

This Scholarship is brought to you for free and open access by Digital Commons @ University of South Florida. It has been accepted for inclusion in ABO: Interactive Journal for Women in the Arts, 1640-1830 by an authorized administrator of Digital Commons @ University of South Florida. For more information, please contact digitalcommons@usf.edu. 


\title{
Representing Camp: Constructing Macaroni Masculinity in Eighteenth-Century Visual Satire
}

\begin{abstract}
This article asks how 'Camp,' as defined in Sontag's 1964 essay, 'Notes on Camp,' might provide a valuable framework for the analysis of late eighteenth-century satirical prints, specifically those featuring images of the so-called 'macaroni.' Discussing a number of satirical prints and contemporary writings on the macaroni, the article reads them against Sontag's text in order to establish its utility as a critical framework for understanding the images' complex relationship of content, form, and function.
\end{abstract}

\section{Keywords}

camp, macaroni, satire, print culture, eighteenth-century, masculinity

\section{Creative Commons License}

(c) (1) (9)

This work is licensed under a Creative Commons Attribution-Noncommercial 4.0 License 
In her important 1964 work, "Notes on Camp," Susan Sontag writes that "Camp taste, has an affinity for certain arts," specifically "clothes, furniture, all the elements of visual décor [and] decorative art" (55). Work on campness in visual and material culture has accordingly focused on those art forms it deems Camp to have the strongest affiliation with, particularly film and television. Amongst studies of Mae West (Robertson), MGM films (Cohan), and RuPaul's Drag Race (Schottmiller), other forms of visual culture - particularly those that precede the twentieth century - are comparatively neglected. This article goes beyond these existing foci to ask how Camp as defined in Sontag's essay might provide a valuable framework for the discussion of late eighteenth-century satirical prints, specifically those featuring images of the so-called "macaroni." In so doing, it will establish these images as objects "saturated with Camp" (Sontag 55), that operate not only through their depiction of a Camp subject, but through their very form and function.

As Sontag notes, Camp exists within a "complex relation to the serious" (62), being at once playful, frivolous, and solemn. Satirical prints similarly hinge upon a complex balance between a serious critique that expressed and constructed the social and political anxieties of a particular period, and a playful reflection upon, and destabilization of, those same anxieties. As images meant to simultaneously provoke pleasure and spark disgust, satirical prints echo Sontag's own response to Camp, which she herself described as "a deep sympathy modified by revulsion" (53). As such, Camp is a particularly apt framework for the genre's discussion. Beyond its apparent ideological aims, the formal characteristics of eighteenth-century graphic satire also accord particularly well with a Sontagian notion of campness. Like Camp itself, which Sontag designates as a "love of the unnatural: of artifice and exaggeration" (53), graphic satire operated through the exaggerated stylization of its protagonists (Janes 4), whose oversized wigs, teetering heels, giant buttons, and spindly legs all signaled their subscription to the muchmaligned "macaroni race" (Brooke 101).

Although many forms of visual satire might be viewed as exhibiting a certain kind of campness, particularly due to the genre's general tendency towards parodic exaggeration, macaroni prints offer a particularly appropriate vehicle through which to discuss eighteenth-century iterations of campness. Showy and specious, ornamented and exaggerated, the macaroni accords with Camp's love of the decorative, its emphasis on texture, and its love of sensuous surface. These concerns are evident in the 1773 print, Lord __ or The Nosegay Macaroni (fig. 1), which presents an effete, aristocratic man dressed in a richly textured three-piece suit, hat fringed with furry spangles, beauty patch poignantly placed, and with a large clutch of flowers at his shoulder: the piece's titular nosegay. This type of figure proliferates across the visual culture of the late eighteenth century, finding his richly-dressed echo in numerous prints published by print-sellers and engravers throughout this period.

As a highly refined, (usually) male character, with a love of color, pattern, and ostentation, and a comparatively feminine manner of self-presentation, the Camp macaroni can also be read through his connection with a specifically queer masculinity. Though George Haggerty has cautioned against using the anachronistic and problematic lens of "twenty-first-century gay culture" that has been applied to figures such as Horace Walpole, Sontagian Camp offers a more complex model than a simple equivalence between certain aesthetic choices and behaviors and same sex desire (Haggerty 544). ${ }^{1}$ Characterized by Sontag as having a "peculiar relation ... [to] homosexuality" (64), wherein it was not necessarily true that Camp taste was homosexual taste, but that there was nevertheless a "peculiar affinity and overlap" between them, Sontag's reading of Camp as possibly, but not necessarily, homosexual aligns with the queer potentiality suggested by satirical prints depicting effete men. As Janes writes, "images 
of effeminacy from the eighteenth century onward operated as a cultural field in which same sex desire could be, but was not necessarily expressed" (Oscar Wilde Prefigured 7). Reflecting the complexities of sexual and gendered identities beyond traditionally-structured categories, Camp - particularly as formulated by Meyer, Cleto and others-is accordingly a powerful tool through which to discuss the knotty relationship between gender, sexuality, and culture during this period. As highlighted in Klein \& Kugler's introduction to this special issue, Camp often "sheds light on the policing of men's affect and dress as 'too feminine', and this in turn offers a means by which to study...how women were defined and limited by these perceptions of gender" (11). Indeed, the omnipresent figure of the macaroni was a highly visible subversion of conceptualizations of masculinity as natural and unadorned; that is, a masculinity formed in specific contradistinction with feminine forms of dress and self-presentation. If the macaroni performs a problematic version of masculinity, this is because this version of masculinity is an explicitly feminine one: too spangled, too ornamental, too refined. As such, a focus on the macaroni's Camp brand of masculinity helps us to reciprocally understand and problematize eighteenth-century conceptions of femininity.

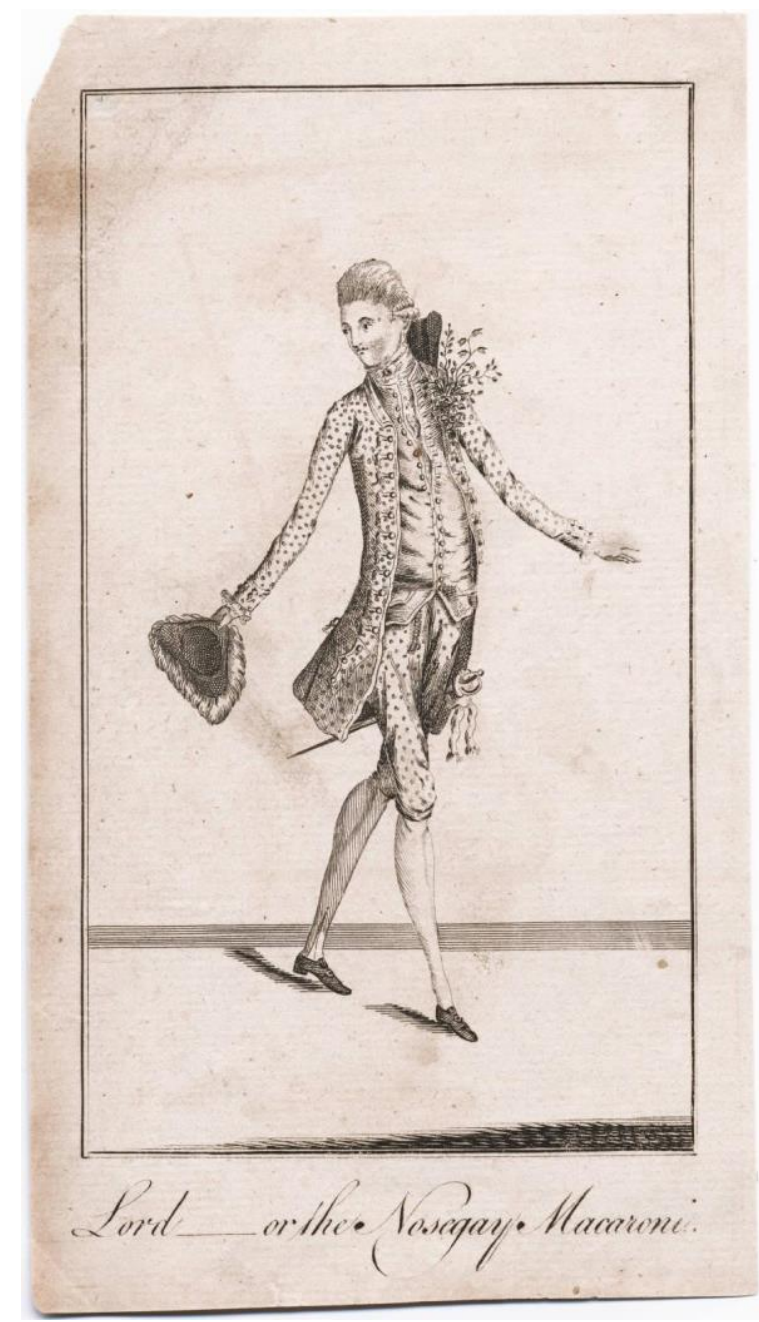

Figure 1. Lord or the Nosegay Macaroni.

Published in The macaroni and theatrical magazine, or, Monthly register of the fashions and diversions of the times.

London: John Williams, February 1773.

Lewis Walpole Library, Farmington, CT.

Courtesy of The Lewis Walpole Library, Yale University 
From the playful relation to the critical and the formal exaggeration that characterizes satirical prints, to the macaroni's indexical relationship to both the ornamental and homosexual, as outlined above, both printed medium and subject thereby operate within a framework of Camp sensibility. Yet despite this accordance, neither the satirical print, nor the macaroni, has been discussed in specific relation to the concept of Camp. ${ }^{2}$ A number of historians have written on the fashions, practices, and identities of the macaroni. In his 1999 article, "That Doubtful Gender": Macaroni Dress and Male Sexualities," Peter McNeil utilized visual and literary satires alongside surviving examples of dress to discuss the relationship between macaroni fashion and sodomitical desire; Amelia Rauser has discussed the macaroni's hair in terms of "eccentric individualism" (Rauser, "Hair, Authenticity" 102); and Sally O'Driscoll has examined the macaroni in terms of his capacity to shed light on eighteenth-century print culture. Following Eve Kosofsky Sedgwick's model, Dominic Janes's Picturing the Closet: Male Secrecy and Homosexual Visibility in Britain (2015), discussed the macaroni as part of the "visual history of the closet and of its spectacle" (12), whilst his most recent work, Oscar Wilde Prefigured: Queer Fashioning and British Caricature, 1750-1900 (2016), expanded upon this focus to foreground the satirical print genre as key to understanding "queer visual 'self-expression'" (5). Finally, although McNeil's recent masterful study of macaroni fashion Pretty Gentlemen: Macaroni Men and the Eighteenth-Century Fashion World (2018), does use the term "camp" in relation to the macaroni's queer identity, their representation has yet to have been subjected to sustained analysis with reference to Sontag's original text.

Building on this existing literature to focus on the macaroni and his depictions, this article will accordingly examine the role of Camp in eighteenth-century visual and material culture. Like Contogouris's essay in this special issue, it examines Camp through its stylistic characteristics, thinking explicitly about the relationship between gendered identities and cultural forms during this period. In so doing, it highlights how the satirical form became coded with gendered and sexual meanings through a repetitive representational process in which the macaroni was central. It argues that through repetitive satirical formulations, and emphases on artificiality, trivial materiality, and reflexivity of form, representations of macaronis employed a consistently and distinctively Sontagian Camp form and accordant visual language that actively engaged with, and contributed to, the ideological formation of a number of transgressive masculine identities. Taking Sontag's assertion that it was in the eighteenth century that "the origins of Camp taste are to be found," specifically in Gothic novels, Chinoiserie, artificial ruins, and most crucially, in "caricature" (56), as its point of disembarkation, the article will unpack the ways in which Sontagian Camp provides a productive framework for discussing both print and print subject.

Just as Sontag writes that "to say all these things are Camp is not to argue that they are simply that" (57), macaroni prints are not simply Camp. Taking Art Nouveau as her example, Sontag continues by noting that:

a full analysis of Art Nouveau, for instance, would scarcely equate it with Camp. But such an analysis cannot ignore what in Art Nouveau allows it to be experienced as Camp. Art Nouveau is full of "content," even of a political-moral sort; it was a revolutionary moment in the arts, spurred on by a utopian vision ... of an organic politics and taste. Yet there is also a feature of the Art Nouveau objects which suggests a disengaged, unserious, "aesthete's" vision. This tells us something important 
about Art Nouveau - and about what the lens of Camp, which blocks out content, is. (57)

Following Sontag's analysis of Art Nouveau, this article unpicks what "the lens of Camp," might tell us about satirical prints. Although in a "full analysis" of macaroni prints, their campness might not necessarily be privileged - indeed, as noted above, this has been the case in the extant literature on such prints - this article shows the productive possibilities of employing such a framework for their interpretation.

Utilizing the ideas proposed in Sontag's account of Camp in combination with later conceptualizations of the term that highlight its deep connections with queerness, this article identifies notions of authenticity/inauthenticity, materiality, and reflexivity as its organizing principles. This article unpacks these themes by utilizing John Dixon's 1773 print, The Old Beau in an Extasy (fig. 2), which is employed as a particularly eloquent point of reference that demonstrates how these ideas were deployed within eighteenth-century satirical prints and writings on the macaroni. Situating Dixon's print within a broader range of printed satirical images from the second half of the eighteenth-century, this article also focuses on prints from the oeuvres of Carington Bowles and Matthew and Mary Darly, the latter of whom produced so many images on this theme, that their premises was known as the "Macaroni Print Shop" (Rauser, Sex and Sensibility 32). ${ }^{3}$ In so doing, this article firmly establishes the macaroni as a figure inscribed through a large and often repetitive body of printed images, whose explicit camp and implicit queerness would have been clearly understood by their viewing subjects. Reading these images against Sontag's framework, this article thereby establishes its utility as a critical framework for understanding both these images, and eighteenth-century Camp itself.

\section{The Old Beau}

The Old Beau in an Extasy includes many elements that images of macaronism typically comprised. Like Lord __ or The Nosegay Macaroni, he is resplendently dressed, here wearing a voluminous and elegantly patterned and colored banyan, which falls open to at his chest to reveal his waistcoat, and which is pulled back at his legs to show off his breeches, stockings, and buckled shoes. He, like many of his counterparts, is seen in the process of having his hair dressed, a practice that repeatedly drew the ire of satirists, and which often included the secondary figure of the macaronified hairdresser, the French "frizeur."

As Rauser has noted, hair was a potent site of both exaggeration and inauthenticity (Rauser, "Hair, Authenticity" 103). Powdered and bewigged, the print's caption also notes the Beau's employment of Chinese Paint for Artificial Bloom, recalling Sontag's definition of Camp objects and persons as "contain[ing] a large element of artifice" (55). The artificial nature of the macaroni was often stressed in contemporary textual representations, with one text from 1774 asserting that the English macaroni was a "detestable copy" of the "French petit maitre [...] the last derives his graces from Nature; the first borrows them from Art" (Helvetius 170). Indeed, as Sontag writes, "nothing in nature can be campy" (55). These physical enhancements go hand in hand with the print's title's explicit identification of the Beau as "Old," locating this artificiality of self-presentation explicitly within a framework of deceit. ${ }^{4}$ By the 1770 s, this was of course, a long-standing trope. From Jonathan Swift's 1732 poem, “The Lady's Dressing Room," which carefully lists the paints and ointments that its female subject used in her cosmetic trickery, to James Gillray's 1792 print, Six Stages of Mending a Face, the print accords with a sustained criticism of the deceptive nature of makeup and dress that spanned the century's entirety. Although the realities of social transvestism have long been questioned 
and problematized, satirical responses to these ideas abounded. This was particularly true with regard to age, with such biases perceptible in prints like Darly's An Old Macaroni Miss-Led (1772), where a richly dressed male is led astray by an apparently duplicitous female companion.

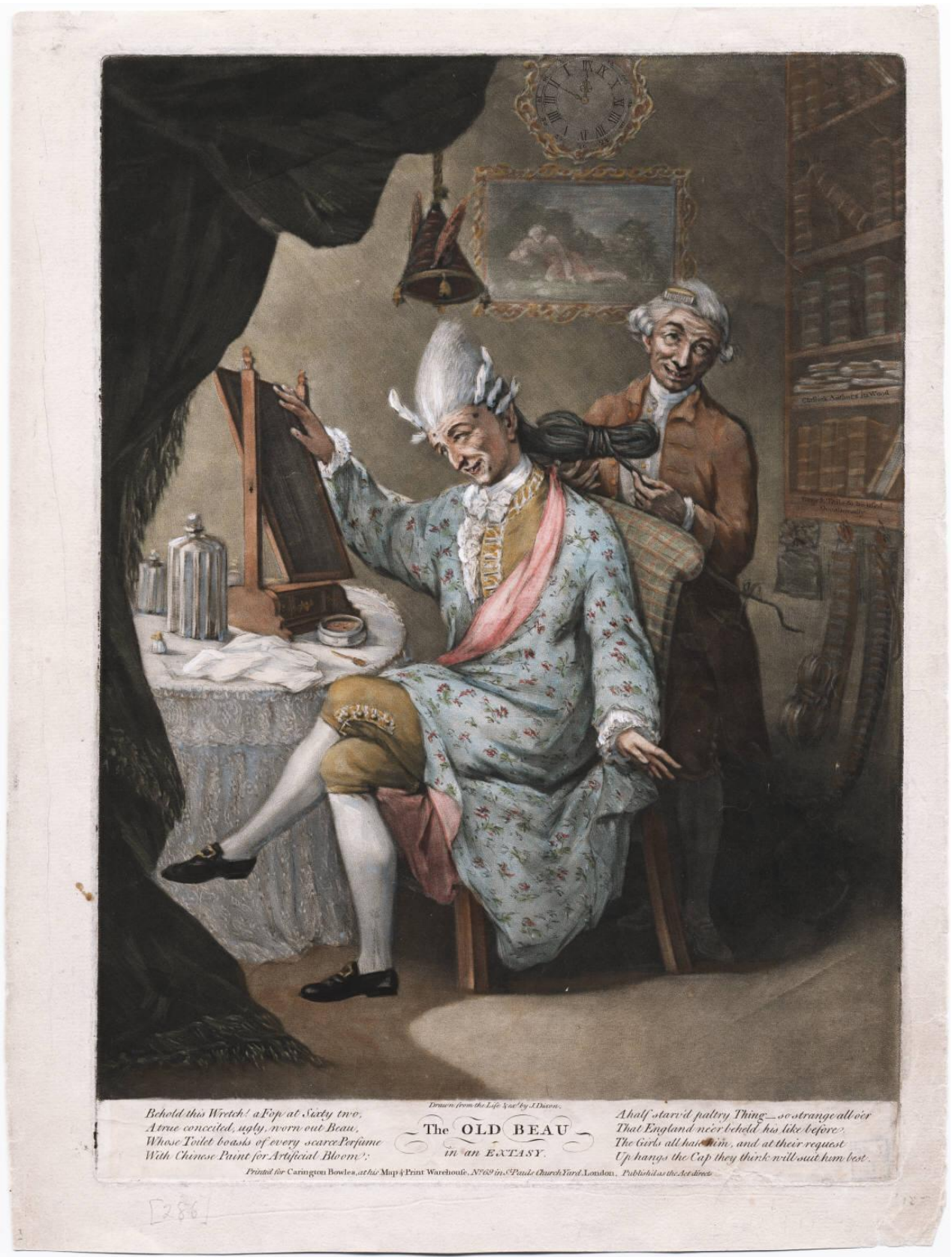

Figure 2. John Dixon, The Old Beau in an Exstasy.

London: Carington Bowles, 1773.

Lewis Walpole Library, Farmington, CT.

Courtesy of The Lewis Walpole Library, Yale University

The dishonest nature of the macaroni went beyond tricks surrounding his physical appearance, however. As indicated by the books which line the Old Beau's shelves-labelled "Classick Authors in Wood" - the macaroni's display of intellect was similarly deceptive; based on appearances alone. This specific device found its echo within literary culture, with authors such 
as Charles Buck describing scenarios in which macaronis professed to having more knowledge than they owned. In his Anecdotes of 1799, Buck wrote that:

there are some books which require peculiar attention in reading, in order to understand them. A spruce macaroni was boasting, one day, that he had the most happy genius in the world. "Ever thing [sic]," said he, "is easy to me: people call Euclid's Elements a hard book; but I read it all yesterday from beginning to end in a piece of afternoon, between dinner and tea time." "Read Euclid," answered a gentleman present, "in one afternoon! How was that possible?" "Upon my honour I did, and never read smoother reading in my life." (181)

Like the perfumes and powders that disguise his age, the macaroni's performance in Buck's anecdote is one predicated on deception; the privileging of appearances, whether true or not. As Sontag writes in Notes on Camp: "to emphasize style is to slight content" (54). Indeed, the emptiness of the macaroni was repeatedly stressed. As the "New and Choice Conundrums" included in the 1773 edition of Lord Chesterfield's Witticisms asked: "Why is the macaroni like a house? Why is he like a cuckold? Why is he like nothing?" (Stanhope 134). Likewise, an anonymous 1775 text featured a macaroni who asked "What's my Thoughts like?" to a female companion, who replied "Like yourself [...] next to nothing" (The Christmas Frolick 70). This nothingness was particularly stark when juxtaposed with the macaroni's external exuberance. In his poem "A Receipt to make a Macaroni," for example, Ewan Clark carefully listed the retinue of adornments that he boasted. From "fourteen pounds" of hair, to "Silk stockings, with clocks interwoven with gold," the poem inventories the typical accoutrements of the macaroni from head to toe, only to become stuck when finally turning to describe his character:

The ornaments outward I've shewn; now I'll shew

The inward Contents of this gold-lettered beau.

---Alas, a mistake!---I've search'd, but in vain,

To find worth in his heart, or wit in his brain (56).

Likewise, James Hurdis's poem "The Village Curate" notes that the macaroni's suit "bedaub'd with gold," "hides the man of little worth" (8). As these satires demonstrate, attempts to define the macaroni repeatedly stressed style over substance, locating macaroni masculinity within a Sontagian campness in which "style [was] everything" (62), and content was correspondingly absent. This binary was also expressed in culinary terms. The third letter of the text Letters from Lysander of 1773 attempts to unpick the origins of the word macaroni, citing the composition of a paste (or pasta) "made of flour, milk, eggs \&c." as key to the term's derivation (10), noting later that the macaroni had a "greater share" of that "paste or powder about them than wit" (11), eventually labelling the macaroni as the accomplished "Bily Brainless" (12). Aside from pasta, the root of the word macaroni was also related to the Italian cake of the same name, which was "sweet to the taste," but had "not the least alimentary virtue" (Adams 240). As John Adams's "Anecdote concerning the origin of Macaraonyism" affirms, this cake became connected with the macaroni through his "trifling performances" consisting of "buffoonery, puns, anagrams, wit without wisdom, and humour without good sense" (240).

\section{Macaroni materiality}


Whether through the listing of the macaroni's trinkets, or by comparing him to food lacking nutritional value, the theorization and definition of macaronism was accordingly explicitly rooted in the material, and specifically, in the trifling nature of that materiality. For every object associated with the macaroni was useless, trivial, and decorative. Like Camp itself, which as noted above, Sontag identified as having an affinity for certain art forms, macaronism was similarly associated with the decorative, the sensuous, and anything lacking in function. His connection with this type of materiality is clear from the various appellations appended to the macaroni, who were repeatedly called "vain fribblers" (Allen 196) and "triflers." The connection between the trifling and a materiality of insignificance was already established by 1749, when Philip Stanhope, $4^{\text {th }}$ Earl of Chesterfield, bestowed the following advice upon his son Philip, who was touring the Italian peninsula:

You are travelling now in a country once so famous for both arts and arms [...] View it, therefore, with care [...] Consider it classically and politically, and do not run through it, as too many of your young countrymen do, musically, and (to use a ridiculous word) knick-knackilly. No piping, nor fiddling, I beseech you; no days lost in poring upon almost imperceptible intaglios and cameos; and do not become a virtuoso of small wares. Form a taste of painting, sculpture, and architecture, if you please; those are liberal arts, and a real taste and knowledge of them become a man of fashion very well. But, beyond certain bounds, the man of taste ends, and the frivolous virtuoso begins (Seabury 102).

The letter reinforced the advice furnished upon Chesterfield's son during the previous year, in which he had written at length on the nature of the "trifling and frivolous mind" (Belfield 64). According to Chesterfield, this mind was "always busied, but to little purpose; it takes little objects for great ones, and throws away upon trifles that time and attention which only important things deserve. Knick-knacks; butterflies; shells, insects, etc., are the subjects of their most serious researches" (Belfield 64). Crucially, as Thomas A. King has convincingly demonstrated, the very term knick-knack was specifically related to same sex desire through its shared etymology with knackers (testicles), being knackered (castrated), and the knickknackatory (a toy-shop apparently kept by effeminate men), making the relationship between such objects and macaroni masculinity all the more compelling (39).

Indeed, it is exactly this kind of knick-knackery that macaronis are frequently depicted as indulging in. Sophia Burrell's poem "The Picture of a Fine Gentleman," lists a vest "Enrich'd with spangles, foils, and lace," "a golden snuff box," and a watch "whose brilliant chain, / A hundred trinkets does sustain" (37). This emphasis was echoed by visual depictions, such as the 1772 print, Pinchee, or the Bauble Macaroni, who is shown holding some kind of handled vessel, deliberately rendered useless due to its pointed base. Similarly, several of William Hogarth's earlier "modern moral progresses" include such trifles alongside their portrayals of effete masculinity. Plate IV of Marriage-à-la-Mode (1745, fig. 4, detail), for example, includes a gaggle of foreign macaronis and similarly Othered servants, one of the latter of whom rifles through a basket of misshapen and random trifles, apparently purchased at auction. Likewise, the pinched fop of his earlier print, Taste in High Life (1742), is shown in raptures over a tea cup and saucer that is so small as to render itself functionless, while surrounded by a variety of other foreign accoutrements, including Chinese porcelain and figurines. ${ }^{5}$ 
Echoing Chesterfield's assertion that "knick-knacks; butterflies; shells, insects, etc.," were the subjects of the trifler's "most serious researches," prints also depicted the macaroni as butterfly catchers. Darly's 1772 print, The Fly Catching Macaroni features a man (likely to be the naturalist Sir Joseph Banks) in typical macaroni dress, standing astride the poles of two globes in an attempt to catch the desired creature. Such images played on the butterfly's patterned wings and brilliant colors to draw an equivalency between captured specimen and its hunter, a relationship that was further affirmed through prints such as The Fluttering Macaroni (c.1772, fig. 4) which literally presented its macaroni subject as a butterfly.

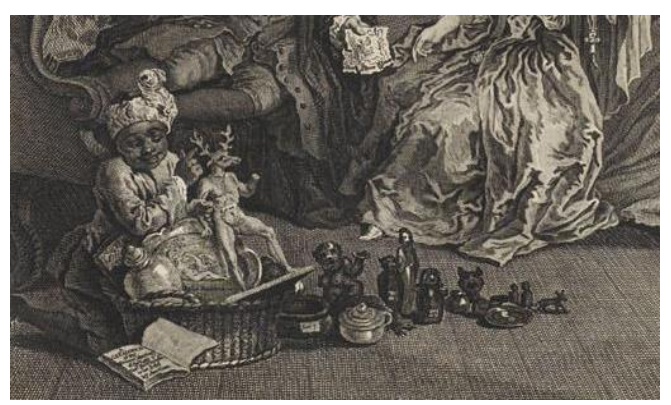

Figure 3. Detail, William Hogarth, Plate IV, Marriage-à-la-Mode.

London: 1745.

Lewis Walpole Library, Farmington, CT.

Courtesy of The Lewis Walpole Library, Yale University

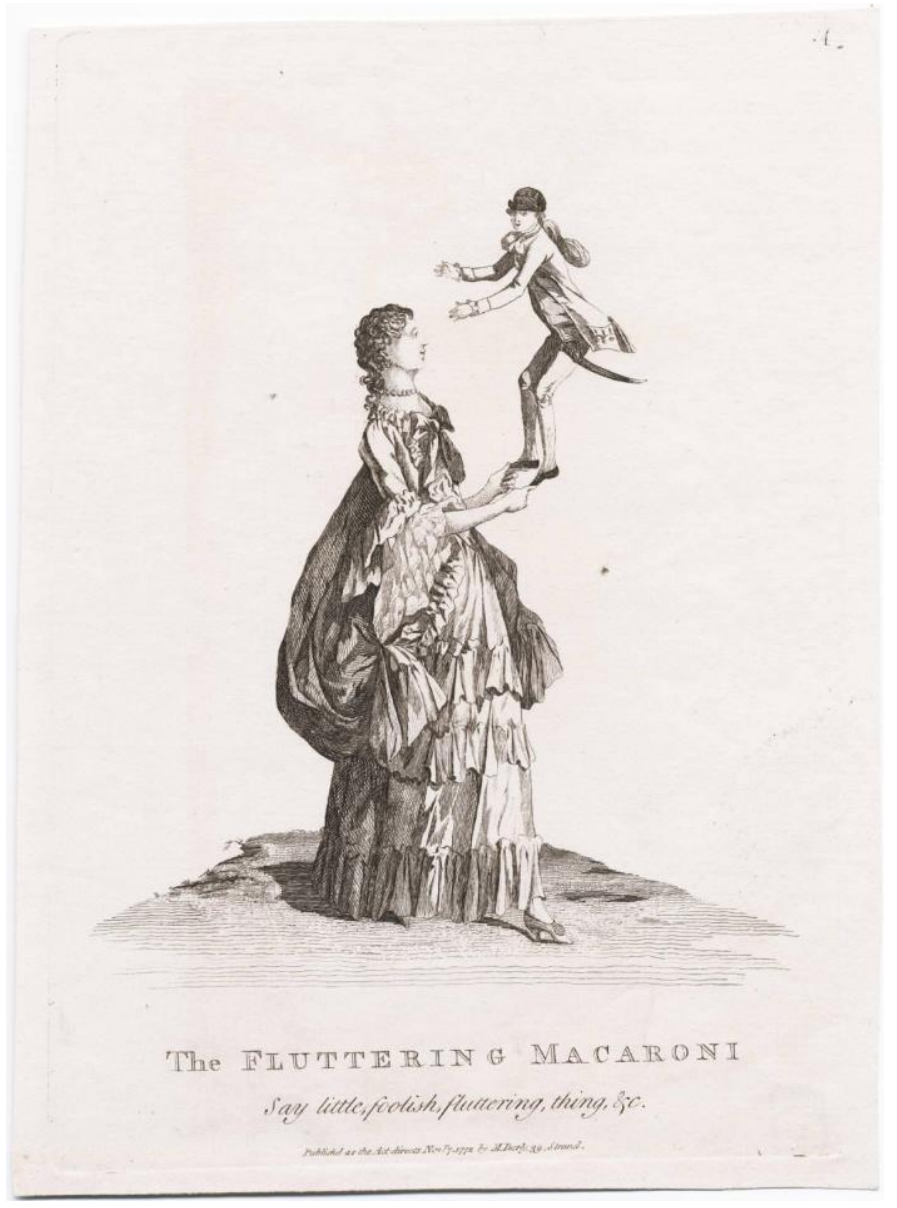


Figure 4. The Fluttering Macaroni.

London: Matthew Darly, 1772.

Lewis Walpole Library, Farmington, CT.

Courtesy of The Lewis Walpole Library, Yale University

Calling the macaroni a "little, foolish, fluttering, thing," the print depicts a miniaturized macaroni, held by the toes as if to stop him from flying away. As such, the print directly conflates macaroni and butterfly, rendering his nature as indivisible from the trifling materiality in which the figure was usually invested. The use of the term "thing" to describe the macaroni in the print's caption is particularly crucial then, as it asserts that the connection between macaroni and trifle goes beyond preference, to function as a comment on the very nature of the macaroni himself, and particularly his propensity for consumption, yet another trait which also likened him to women. ${ }^{6}$

The macaroni as consumable is a consistent trope in eighteenth-century visual and material culture. While satirical images such as Isaac Taylor's Cupid turn'd auctioneer (1772), which depicts a macaroni on sale at an auction, certainly reinforce the objecthood of this figure, this connection is perhaps nowhere more palpable than in the small-scale wares featuring images of macaronis. The collections of the Victoria and Albert Museum include a number of ceramics that employ depictions of, or which take the form of, macaronis, such as a pearlware tea canister and cover $(126 \mathrm{~A}-1874,1790)$ decorated with an image of a fat macaroni in an impossibly tall wig. ${ }^{7}$ Like The Fluttering Macaroni, these objects reinforce the idea that the macaroni was not merely characterized by his love of such trinkets, but that he himself was a trinket: a decorative and thereby explicitly Camp object that privileged surface over interiority, ornamentation over functionality. Crucially, some of these objects had direct relationships with that other vehicle for the consumption of the macaroni-graphic satire. An earthen-ware jug from around 1775 (414:1145-1885), for example, is decorated with a version of "The Macaroni Sportsman," adapted from a work published by Darly in 1772, and transfer printed in red enamel onto the jug's surface. Likewise, a reduced-scale version of the Darly print The Isis Macaroni, from the same year, is found in a collection of draft watch papers from the late eighteenth-century, now held in the British Museum (132.136). The object's reduced size and consequent portability highlight the nature of these prints as themselves objects to be consumed, a kind of reflexive self-awareness of their function that locates such images within an explicitly Camp sensibility.

\section{Reflexive and reflective images}

Indeed, the idea of reflexivity firmly situates these images within a Sontagian conceptualization of Camp, which she identifies as "see[ing] everything in quotation marks. It's not lamp, but a 'lamp'; not a woman, but a 'woman'. To perceive Camp in objects and persons is to understand Being-as-Playing-a-Role. It is the farthest extension, in sensibility, of the metaphor of life as theater" (56). Graphic satire's own campness correspondingly works through an emphasis on its own performance of the representational process; with the viewing subject being actively reminded of their participation within this dynamic. Here Christina Lupton's conception of reflexivity as sketched out in Knowing Books: The Consciousness of Mediation in EighteenthCentury Britain (2011) is particularly useful: with such prints exhibiting a comparable "sentience that emanates from their material form in print and announces itself as a knowledge of the relationship between an author, narrator and audience," to that which Lupton identifies in contemporary literary culture (ix). Like Looser, whose article in this issue refers to this kind of self-awareness in Austen's juvenilia as a kind of "campy knowing" (8), and Beaulieu, whose 
account of Sterne's A Sentimental Journey, also in this special issue, figures Yorick as highly conscious of the sentimentality he encounters, I identify such reflexivity, or the "ability to see the world in quotes" (11), as central to any conception of Camp.

The Old Beau in Extasy is a particularly useful example through which to consider the selfconsciousness of the satirical form, hanging, as it does, on a complex dynamic of reflection and reflexion. The print plays with several metaphors of reflection, an idea that is compounded and intensified through the layering and interaction of various visual devices. These work on several distinctive registers: most obviously, the "Old Beau's" ecstasy seems to have been provoked by his gazing at his own reflection in the mirror to which he holds. Like the Darly print, The Shuffling Macaroni (1772), the Beau is entranced by his own image. Yet this is only the most literal instance of reflection in the piece. His hairdresser also functions as a mirrorimage of the Beau. Although lacking his resplendent dress, the hairdresser's form nevertheless echoes the expressions and gestures of his client: where the Beau leans in, he leans away; where the Beau's hands are spread wide, his own are drawn in; and finally, whilst the Beau looks down to his own visage, he gazes up and away: each man united by their shared look of enjoyment, or the piece's titular "extasy."

Finally, the print also encourages us to think about the relationship between reflection and representation, particularly through the highly deliberate textual assertion that the print was in fact "Drawn from the Life." This inclusion is reminiscent of Dominic Janes's contention that satirists "needed to be intimately familiar with that which they chose to mock" (Oscar Wilde Prefigured, 4). Indeed, the print's revelation that it was taken from life reveals an intimate familiarity and perhaps even complicity on the part of the artist, John Dixon, whose presence in the semi-private space of the Beau places him within a problematic ménage a trois of reciprocal looking, gazing, and reflecting. Both the print's emphasis on looking as act, and its status as "from life," relates it directly to another of Dixon's prints, The Arrest of 1768, which is similarly identified as "drawn from a late real Scene." The print features the macaronified and tellingly-named figure, "Sir Fopling Flutter," who "through his Glass, / Inspects the Ladies as they pass." Yet Sir Fopling's licentious gazing is interrupted by a Bailiff, who pulls an onanistic hand from his prisoner's trousers. Indeed, looking, particularly through a looking glass, was one of the key devices that connected the macaroni to forms of deviant sexuality. The 1781 text, Woodbury; or, the memoirs of William Marchmont, recalls how the macaroni's glass, which was "tied to his botton-hole," was used to "contemplate the beauties of the lovely Lucy" (49), with this pseudo-connoisseurial gesture finding an explicitly queer echo in prints such as Refin'd Taste (fig. 5). 


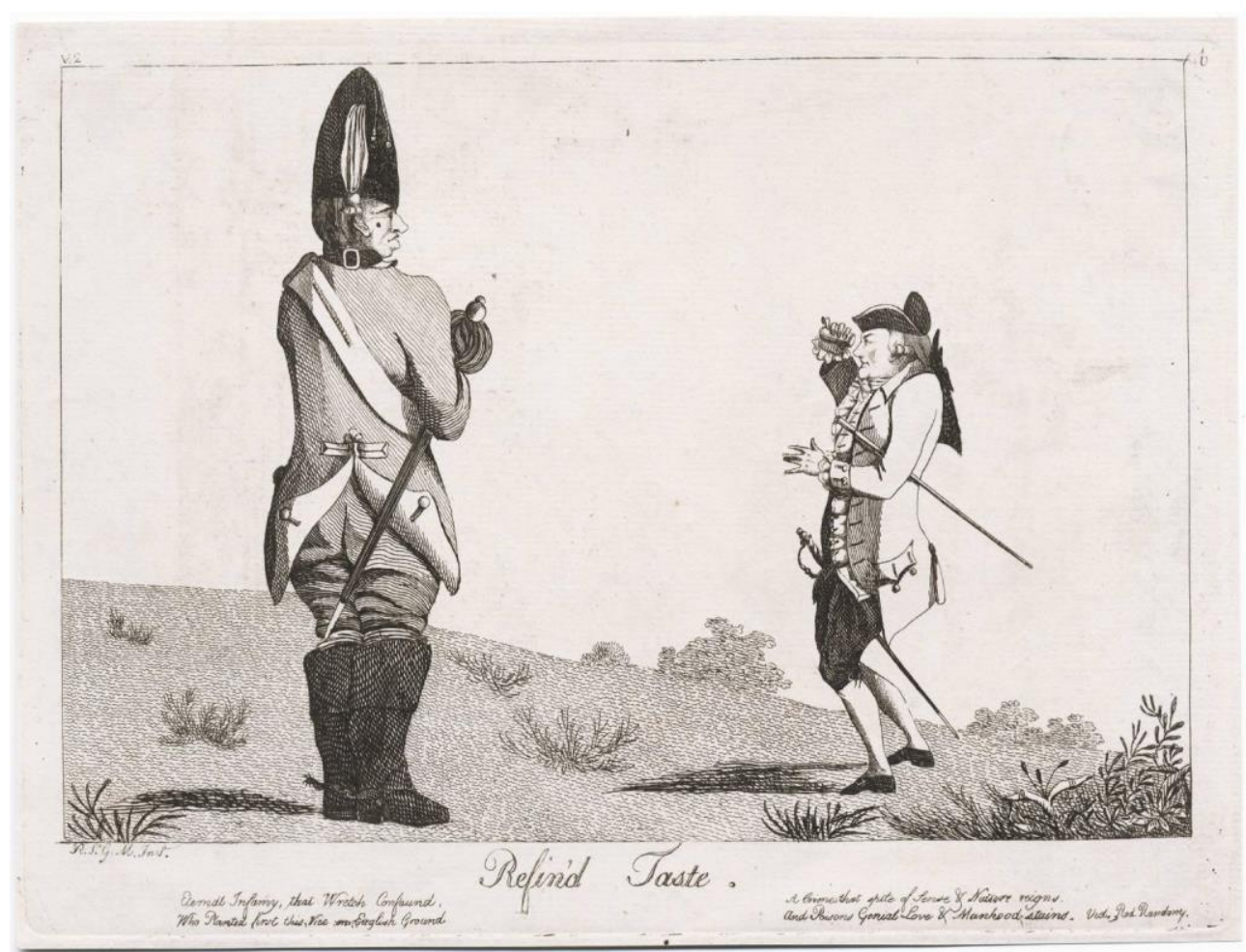

Figure 5. Refin'd Taste.

London: Matthew Darly, 1773.

Lewis Walpole Library, Farmington, CT.

Courtesy of The Lewis Walpole Library, Yale University

The above image presents a finely-dressed macaroni, clutching an eyeglass to his face, which he uses to inspect the much larger object of his affections, whose coat is provocatively peeled back to reveal the outline of his buttocks. If any doubt as to the print's inference was to remain, its poetic caption reads: "Eternal Infamy, that Wretch Confound, / Who Planted first this Vice on English Ground, / A Crime that spite of Sense \& Nature reigns, / and Poisons Genial Love \& Manhood stains." As Janes has compellingly argued, such satire must be situated within a visual tradition that prefigured Oscar Wilde's queer performativity through a "ribald satirical tradition [that] associated dandified performances with sodomitical desires" (Oscar Wilde Prefigured 2). Here again, Camp, with its suggestive yet complex relationship with same sex desire, provides a particularly useful model to invoke.

Regardless of the specific variety of male sexual deviancy invoked in Dixon's images, the artist's proximity to the scenes remained potentially compromising. As Janes argues, satirists "were frequently implicated in the scenes that they affected to mock," as "prints reflected the foibles of fashionable society" (Oscar Wilde Prefigured 4). Yet this representative process goes beyond reflection to encompass reflexion, the active deployment of visual and rhetorical devices that function as much as a commentary on gender and masculinity as they do on how prints "worked" in the late eighteenth century. In the case of The Old Beau in an Extasy, this reflexive reflection upon the idea of looking at the scene is encouraged both by the artist's described physical presence in the image, as well as the viewer's identification with this position. This association is emphasized by the placement of the proscenium device of the dark curtain, which is pulled away to reveal the almost stage-lit scene before us, and which therefore reinforces the fact that we too are looking at, and are implicated within, the scene. 
Further to the external viewer of the print, the figure of the macaroni is often his own viewing agent: a simultaneous enactment of viewing subject and viewed object in which the print's use of Camp quotation is deliberately laid bare. This is apparent in a number of macaronic tropes in which the printed protagonist encounters, and even participates within, the performance of viewing or making an image of macaronic masculinity. Firstly, this is seen in images of the "macaroni painter," a genre typified by prints such as The Macaroni Painter, or Billy Dimple Sitting for his Picture (1772), or The Paintress of Macaronis (1772, fig. 6). In The Macaroni Painter the titular artist sits opposite his well-dressed counterpart, with the depicted process of his painting a portrait functioning as a deliberate comment on the representational process happening both within the narrative content of the print, and that which constitutes the function of the print itself. In The Paintress of Macaronis (whose own gender-performance and identity is complicated and called into question through her identification as a macaroni) this reflexivity is taken one step further, as reinforced by the mirrored surface featured in the background of the image (McNeil, Pretty Gentlemen 112). As the Paintress gazes at the viewer while she paints a notably macaronified portrait, she thereby reproduces their own countenance, implicating the viewer as both a macaroni, and within the representative process of the print, one that is concurrently enacted by their own looking at that very same image.

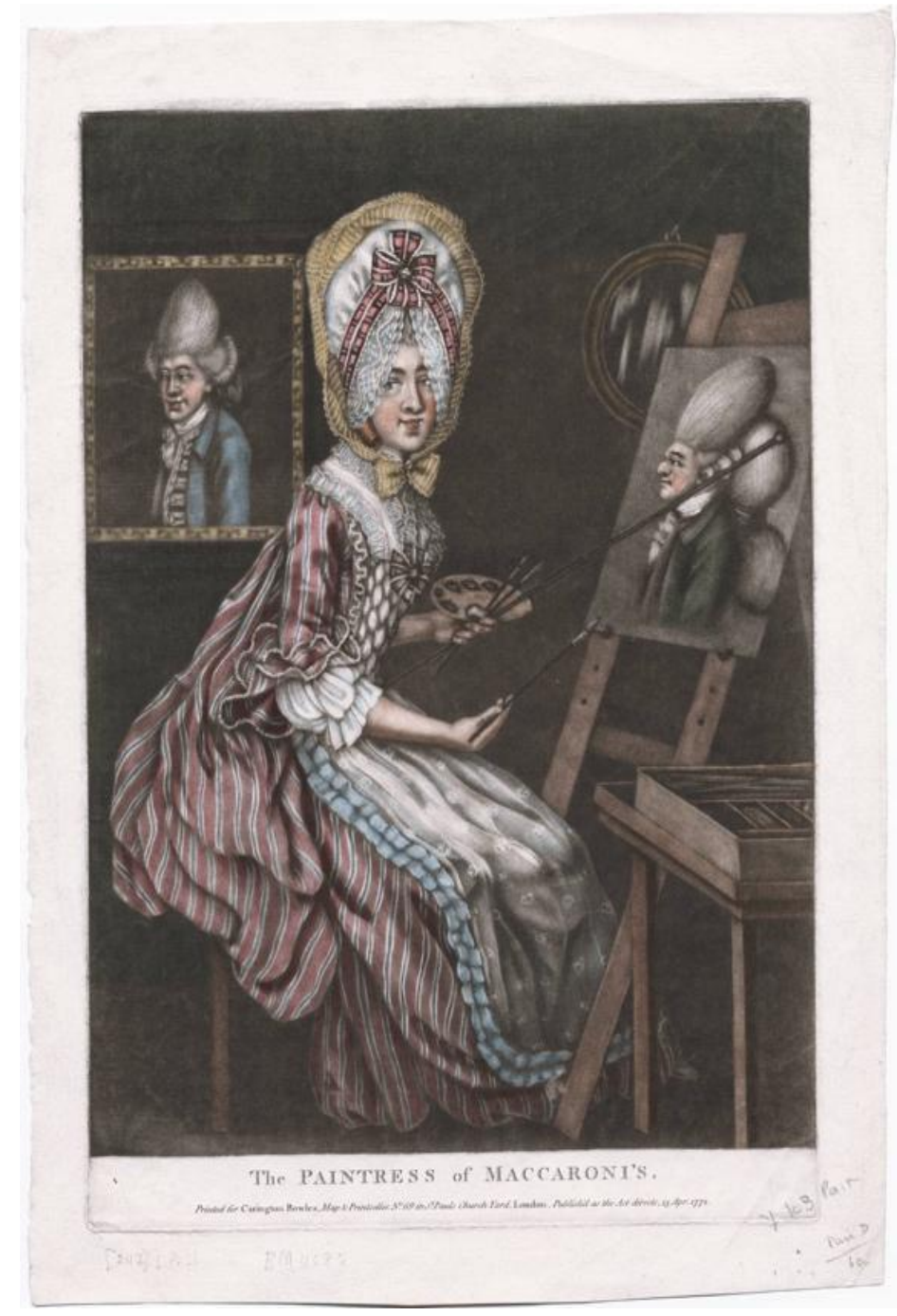

Figure 6. The Paintress of Macaronis. London: Carington Bowles, 1772. 
Lewis Walpole Library, Farmington, CT.

Courtesy of The Lewis Walpole Library, Yale University

This is a device that also finds its form within images of the print-shop window, such as the Carington Bowles print, Miss Macaroni and her Gallant at a Print Shop (1773). Featuring well-known prints such as the iconic How d'ye like me? (1772) and the aforementioned The Macaroni Painter and The Paintress of Macaronis, these inclusions deftly render the print's viewing macaronis as the consumers of images of macaronis, who, as demonstrated above, are depicted as viewing and viewed themselves. This genre of satirical print is also exemplified by Darly's 1772 print, The Macaroni Print Shop (fig. 7). The print depicts a retinue of recognizable macaroni types who stare at previously published images of macaronis as displayed in the windows of Darly's own print shop. These include The Fly Catching Macaroni of the same year, whose presence, like that of The Macaroni Painter and The Paintress of Macaronis in Miss Macaroni and her Gallant at a Print Shop, is surely an ironic comment upon the objecthood of the depicted macaronis. Through parodic reflexivity, images of such self-aware macaronis were, therefore, themselves Camp by virtue of their medium. As images which utilized visual signifiers of campness, presented through a visual genre that was in its very essence Camp in order to make a witty comment on the artificial, excrescent, and thereby Camp, nature of modern masculinity, we find a compelling convergence of form, function, and meaning; of reflection and reflexion.

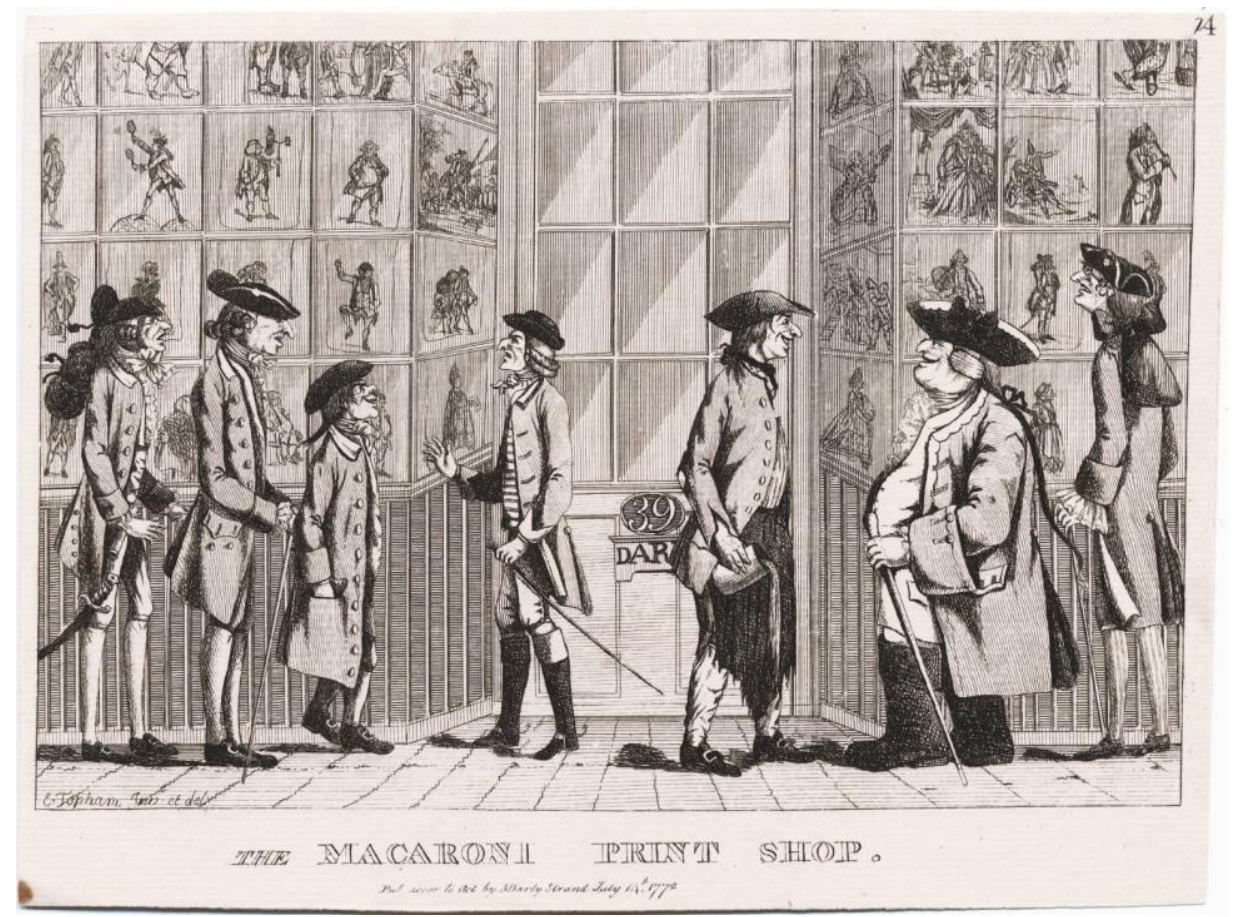

Figure 7. The Macaroni Print Shop.

London: Matthew Darly, 1772.

Lewis Walpole Library, Farmington, CT.

Courtesy of The Lewis Walpole Library, Yale University

As a figure known primarily through his appearances within visual satire and its associated material culture, the very existence of the macaroni was defined by and constituted through representation. Tellingly, the definition of the macaroni from the Letters from Lysander ends with the following: 
we have a variety of macaronies, and our print-shops exhibit to us daily their elegant pictures: we have herculean as well as diminutive fribbles, and aged as well as youthful coxcombs.... I will next week send you a collection of macarony prints to adorn your hall with, which will convey to you a better idea of the originals than I can here possibly give you. (13)

Here then, the macaroni is presented as indivisible from the printed form in which he was displayed; indeed, the prints are identified as providing a "better idea" of the macaroni than the "original," that is, the "real-life" macaroni. In describing the variety of macaronis extant, the author explicitly references Darly's infamous and extensive series of macaroni prints, which together produced a kind of taxonomy of macaronism. Consolidated in this unvarying repertory of images that constituted this genre of satirical print, the proliferation of the macaroni and his representations resulted in a specific visual language of transgressive masculinity that privileged a Sontagian campness - as specifically articulated through commentary on inauthenticity, frippery, and reflexivity-amongst its key signifiers. Examining macaroni prints through the lens of Camp thereby provides a means by which to understand iteration as a dynamic cultural process that not only typified late eighteenth-century forms of representation, but which functioned to construct gender, sexuality, and even the genre of the satirical print during this period.

\footnotetext{
${ }^{1}$ The knotty interrelationship between same-sex desire and Camp can be profitably situated in relation to George Haggerty's account of the overlapping complexities of queerness and homosexuality in "Queering Horace Walpole," SEL: Studies in English Literature 1500-1900, vol. 46, no. 3, Summer 2006, pp. 543-561.

${ }^{2}$ In Thomas A. King's account "Performing 'Akimbo"', Sontagian Camp is explored in relation to eighteenthcentury homosexuality, taste and visual culture, but notably a specific analysis of the macaroni is absent from his discussion. King, "Performing 'Akimbo': Queer Pride and Epistemological Prejudice." The Politics and Poetics of Camp, edited by Moe Meyer. Routledge, 1994, pp. 23-50.

${ }^{3}$ For a more in-depth discussion of Darly's macaroni prints, see Shearer West, "The Darly Macaroni Prints and the Politics of 'Private Man." Eighteenth-Century Life, vol. 25, no. 2, Spring, 2001, pp. 170-182, and McNeil, 2018, pp. 83-85.

${ }^{4}$ On the artificiality of macaronis, see Rauser, "Hair, Authenticity, and the Self-Made Macaroni."

5 On Hogarth and "otherness," see Angela Rosenthal \& Bernadette Fort, The Other Hogarth: Aesthetics of Difference (Princeton, NJ: Princeton University Press, 2002); \& David Porter, "A Wanton Chase in a Foreign Place: Hogarth and the Gendering of Exoticism.” Studies in Eighteenth-Century Culture, vol. 33 no. 1, 2004, pp. 399-413.

${ }^{6}$ On representations of the female consumer, see my chapter "Taste $\grave{a}$-la-mode: Consuming foreignness, picturing gender." Materializing Gender in Eighteenth-Century Europe, edited by Jennifer Germann and Heidi A. Strobel. Routledge, 2016, pp. 73-80.

${ }^{7}$ For more on macaroni ceramics and other forms of material culture, see McNeil, 2018.
} 


\section{Works Cited}

Primary Texts

Anon. Letters from Lysander: or, amusement for the good-humoured. London, W. Davis, 1773.

Anon. The christmas frolick; or, Mirth for the Holidays. Consisting of A great Number of admirable Stories never before printed; with a select Collection of others, from rare, old, and scarce Books. London, 1775.

Anon. Woodbury: or, the memoirs of William Marchmont, Esq. and Miss Walbrook. In letters. Dublin, 1781.

Adams, John. Anecdotes, bons-mots, and characteristic traits of the greatest princes, politicians, philosophers, orators, and wits of modern times. London, 1789.

Allen, Charles. The Polite lady; or, A course of female education: in a series of letters, from a mother to her daughter. London, 1773.

Brooke, Frances. The Excursion. Dublin, 1777.

Buck, Charles. Anecdotes, religious, moral and entertaining, alphabetically arranged, and interspersed with a variety of useful observations. London, 1799.

Burrell, Sophia. Poems. Dedicated to the Right Honourable the Earl of Mansfield. London, 1793.

Clark, Ewan. Miscellaneous poems. London, 1779.

Helvetius, Mr. The child of nature, improved by chance. A philosophical novel. By Mr. Helvetius. London, 1774.

Hurdis, James. The village curate, a poem. London, 1788.

Swift, Jonathan. The Lady's Dressing-Room, A Poem. Dublin, 1732.

Stanhope, Philip. Lord Chesterfield's letters to his son and godson, edited by H. H. Belfield. London, Maynard, Merrill, \& Co. 1897.

---. Lord Chesterfield's Letters to his Son, edited by J. B. Seabury. New York, Boston \& Chicago, Silver, Burdett \& Co. 1902.

---. Lord Chesterfield's witticisms; or, the grand pantheon of genius, sentiment, and taste. London, 1773.

Secondary Texts 
Cohan, S. Incongruous Entertainment: Camp, Cultural Value and the MGM Musical. Duke University Press, 2005.

Janes, Dominic. Oscar Wilde Prefigured: Queer Fashioning and British Caricature, 17501900. Chicago University Press, 2016.

---. Picturing the Closet: Male Secrecy and Homosexual Visibility in Britain. Oxford University Press, 2015.

King, Thomas A. "Performing 'Akimbo': Queer Pride and Epistemological Prejudice." The Politics and Poetics of Camp, edited by Moe Meyer. Routledge, 1994, pp. 23-50.

Lupton, Christina. Knowing Books: The Consciousness of Mediation in Eighteenth-Century Britain. University of Pennsylvania Press, 2011.

McNeil, Peter. “"That Doubtful Gender': Macaroni Dress and Male Sexualities.” Fashion Theory, vol. 3, no. 4, 1999, pp. 411-447.

---. Pretty Gentlemen: Macaroni Men and the Eighteenth-Century Fashion World. Yale University Press, 2018.

O'Driscoll, Sally. "What Kind of Man Do Clothes Make? Print Culture and the Meanings of Macaroni Effeminacy." Studies in Ephemera: Text and Image in Eighteenth-Century Print, edited by Kevin Murphy \& Sally O’Driscoll. Bucknell University Press, 2013.

Porter, David. "A Wanton Chase in a Foreign Place: Hogarth and the Gendering of Exoticism.” Studies in Eighteenth-Century Culture, vol. 33 no. 1, 2004, pp. 399-413.

Rauser, Amelia. "Hair, Authenticity, and the Self-Made Macaroni." Eighteenth-Century Studies, vol. 38 no. 1, 2004, pp. 101-117.

---. "Sex and Sensibility: Hair in the Macaroni Caricatures of the 1770s." Hair: Untangling a Social History, edited by Penny Jolly. Tang Teaching Museum and Art Gallery, 2004.

Robertson, Pamela. Guilty Pleasures: Feminist Camp from Mae West to Madonna. I. B. Tauris, 1996.

Rosenthal, Angela \& Fort, Bernadette. The Other Hogarth: Aesthetics of Difference. Princeton University Press, 2002.

Schottmiller, C. “'Excuse My Beauty!': Camp Referencing and Memory Activation on RuPaul's Drag Race," Sontag and the Camp Aesthetic, edited by B. E. Drushel \& Brian M. Peters. Rowman \& Littlefield, 2017.

Sontag, Susan. 'Notes on "Camp,"'Camp: Queer Aesthetics and the Performing Subject, edited by Fabio Cleto. Edinburgh University Press, 1999, pp. 53-65.

West, Shearer. "The Darly Macaroni Prints and the Politics of 'Private Man."' EighteenthCentury Life, vol. 25, no. 2, Spring, 2001, pp. 170-182. 